\title{
Sistem Kontrol Misting Antiseptic Automatic Pada Pintu Masuk Berbasis Microcontroller
}

\author{
Ahmad Faisal ${ }^{1}$, Habibullah ${ }^{2}$ \\ 12 Universitas Negeri Padang \\ Jl. Prof Dr. Hamka Air Tawar, Padang Indonesia \\ ahmadfaisal780@gmail.com, habibullah@ft.unp.ac.id
}

\begin{abstract}
Viruses are very easy to spread and cause disease. One of the ways to minimize the spread of the virus is by washing the body surface using an antiseptic using the misting method. The purpose of this research is to make a device that can reduce the spread of the virus with an automatic antiseptic misting control system at the entrance based on a microcontroller. This study uses experimental methods and this research was conducted at the author's house. The device is controlled by the ESP32-CAM which starts when the controller is connected to the internet via Wi-Fi. The E18-D80NK sensor will detect an object so that the tool will send image data by the 0V2640 camera and temperature data by the MLX90614 sensor to the Telegram application which will be monitored by the operator. Operators can also see the situation around the device directly by using the Telegram application message bar, both in the form of images and temperatures. After the tool sends images and object temperature data, the water pump machine will work for 2 seconds to apply pressure to the antiseptic so that the liquid will flow to the end of the channel or $0.2 \mathrm{~mm}$ nozzle so that the liquid will come out as mist or dew from the antiseptic liquid. The results of this study are successful because the tool can work well according to the design and has a $100 \%$ success rate for sending data to the Telegram application.
\end{abstract}

Keywords- ESP32-CAM Controller, OV2640 Camera, MLX90614 Sensor, E18-D80NK, Telegram

Abstrak - Virus sangat mudah menyebar dan menyebabkan penyakit. Penyebaran virus dapat diminimalisir salah satunya dengan membasuh permukaan tubuh menggunakan antiseptik dengan metode pengkabutan. Tujuan penelitian ini adalah membuat alat yang dapat mengurangi penyebaran virus dengan sistem kontrol pengkabutan antiseptik otomatis pada pintu masuk berbasis mikrokontroler. Penelitian ini menggunakan metode ekperimen serta penelitian ini dilakukan di rumah penulis. Alat ini dikendali oleh ESP32-CAM yang dimulai ketika kendali tersebut terhubung ke internet melalui Wi-Fi. Sensor E18-D80NK akan mendeteksi adanya objek sehingga alat akan mengirimkan data gambar oleh kamera 0V2640 serta data suhu oleh sensor MLX90614 ke aplikasi Telegram yang nantinya akan di pantau oleh operator. Operator juga dapat melihat keadaan sekitar alat secara langsung dengan menggunakan bilah pesan aplikasi Telegram baik itu berupa gambar maupun temperatur. Setelah alat mengirimkan gambar serta data suhu objek, mesin pompa air akan bekerja selama 2 detik untuk memberikan tekanan kepada antiseptik sehingga cairan akan mengalir ke ujung saluran atau Nozzle 0.2mm sehingga cairan akan keluar sebagai kabut atau embun dari cairan antisetik tersebut. Hasil dari penelitian ini berhasil karena alat dapat bekerja dengan baik sesuai dengan rancangan serta memiliki tingkat keberhasilan alat untuk mengirim data ke aplikasi Telegram sebesar $100 \%$.

Kata kunci- Kendali ESP32-CAM, Kamera OV2640, Sensor MLX90614, Sensor E18-D80NK, Telegram

\section{Pendahuluan}

Terlularnya suatu virus, terjadi ketika virus masuk ke induk semangnya. Dimulai dengan menempel, lalu masuk dan berkembang biak di dalam sel dalam tubuh sehingga disebut sebagai infeksi[1]. Infeksi virus ini menyebabkan penyakit dengan gejala-gejala yang bervariasi baik itu ringan maupun berat bahkan kematian.

Kebanyakaan infeksi virus dapat menular dari manusia ke manusia lain seperti yang terjadi saat sekarang ini yaitu terjadinya pandemi COVID-19 (Coronavirus Diseases 2019) yang mana virus ini dapat menyebabkan infeksi pernafasan sehingga virus ini dapat menyebabkan kematian.

Salah satu cara virus untuk dapat menyebar adalah dengan cara penyebaran percikan-percikan (Droplet) dari hidung maupun mulut dari penderita. Percikan tersebut akan menempel pada tubuh manusia yang sehat dan sewaktu-waktu virus tersebut akan masuk ketika terhirup sehingga virus akan berkembang biak di dalam tubuh manusia tersebut.

Salah satu tempat berkemungkinan besar terjadinya penyebaran virus secara cepat adalah suatu tempat yang berkemungkinan terjadinya kerumunan atau banyak orang di satu tempat dalam waktu yang relatif lama yaitu pada kantor, pasar, taman bermain, sekolah, dan lain sebagainya. Telah dilakukan metode untuk pencegahan penyebaran virus salah satunya adalah metode pengecekkan suhu[2]. Tetapi metode pengecekkan suhu dilakukan hanya sebagai pemantauan saja bukan untuk membunuh virus di lingkungan sekitar. Jadi, diperlukan juga suatu usaha untuk mencegah terinfeksinya virus dari lingkungan baik itu dari seseorang maupun benda. 
Salah satu cara usaha untuk mencegah kemungkinan penularan dan penyebaran virus di lingkungan salah satunya adalah menggunakan antiseptik sebagai pembunuh virus dengan metode Misting atau pengkabutan[3]-[6]. Metode tersebut memiliki ujung saluran berbentuk Nozzle serta menggunakan mesin pompa air untuk memberikan tekanan pada antiseptik agar dapat mengalir ke ujung saluran[7].

Dengan kendali ESP32-CAM, penulis merancang sistem pompa air yang dapat dikontrol otomatis bedasarkan aktifnya sensor Infrared E18-D80NK serta membaca nilai suhu objek dengan sensor MLX90614 dan mengambil gambar dengan modul kamera OV2640 yang nantinya akan dikirim ke operator melalui aplikasi Telegram[8]-[13]. Operator juga dapat melakukan pemantauan secara langsung melalui aplikasi tersebut dengan menggunakan perintah-perintah pada bilah pesan[14], [15]. Jadi, Manfaat dari alat ini adalah meminimalisir kemungkinan penyebaran virus dari lingkungan baik itu seseorang maupun benda sehingga manusia hidup sehat dan besih dan dapat dilakukan pemantauan langsung terhadap manusia yang kurang sehat oleh operator.

\section{Metode}

Metode penelitian tentang rancangan sistem kontrol Sistem Kontrol Misting Antiseptic Automatic Pada Pintu Masuk berbasis Microcontroller adalah berupa percobaan atau eksperimen dimana terdapat perancangan Hardware serta Software.

\section{PERANCANGAN DAN PEMBUATAN ALAT}

\section{A. Blok Diagram}

Blok diagram merupakan suatu metode yang digunakan sebagai pengambaran secara umum atau alur sistem kerja alat tentang bagaimana hubungan keseluruhan rancangan alat. Blok diagram dari "Sistem Kontrol Misting Antiseptic Automatic pada Pintu Masuk Berbasis Microcontroller" dapat perhatikan pada gambar berikut ini

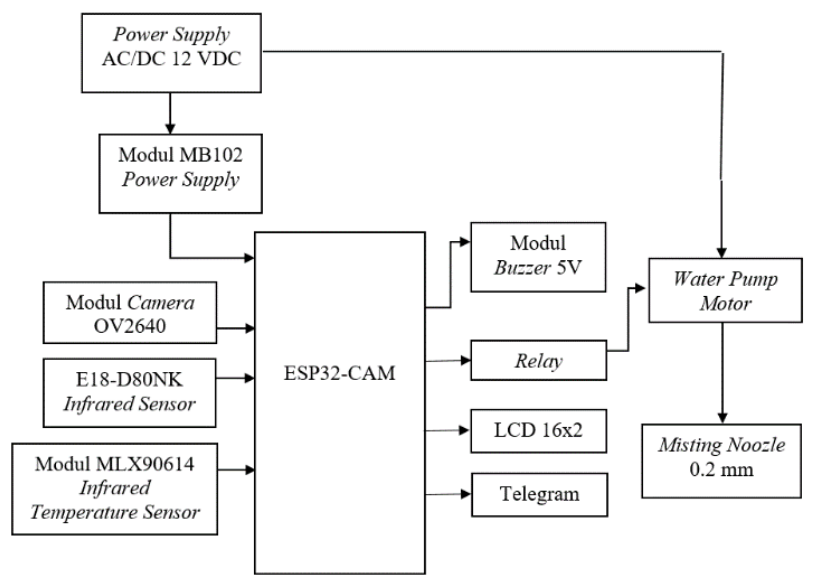

Gambar 1. Blok Diagram Alat
Penjelasan masing-masing blok diagram diatas dipaparkan pada berikut ini :

1. Power Supply AC/DC 12 VDC

Berfungsi sebagai pengubah tegangan 220 VAC (sumber PLN) menjadi 12 VDC yang nantinya akan digunakan sebagai penyuplai daya pada Water Pump Motor dan sebagai input tegangan dari modul MB102.

2. Modul MB102 Power Supply

Berfungsi sebagai pengubah tegangan 12 VDC menjadi 5 VDC dan 3,3 VDC yang nantinya akan digunakan pada kendali ESP32-CAM sebagai kendali serta penyuplai tegangan pada sensor-sensor, buzzer, relay, serta LCD $16 \times 2$.

3. Mikrokontroler ESP32-CAM

Berfungsi sebagai pusat pengolahan data atau kendali. Mikrokontroler ini diprogram dari instruksi-instruksi yang telah dirancang. Maka, dapat dikatakan sebagai otak dari seluruh rangkaian.

4. Modul Camera OV2640

Berfungsi untuk mengambil sinyal berupa gambar yang nantinya akan diproses oleh mikrokontroler ESP32-CAM untuk dikirimkan ke aplikasi Telegram.

5. E18-D80NK Infrared Proximity Sensor

Berfungsi sebagai pendeteksi adanya objek didepan sensor yang nantinya akan diproses oleh mikrokontroler ESP32-CAM.

6. MLX90614 Infrared Temperature Sensor

Berfungsi untuk mengambil sinyal berupa suhu objek yang nantinya akan diproses oleh mikrokontroler ESP32-CAM untuk dikirimkan ke aplikasi Telegram.

7. Modul Buzzer 5V

Berfungsi sebagai indikator berupa bunyi ketika pembacaan suhu, dan pengiriman gambar serta nilai suhu pada aplikasi Telegram selesai.

8. Relay

Berfungsi sebagai saklar (Switch) pada motor pompa air (Water Pump Motor) 12 VDC.

9. LCD $16 \times 2$

Berfungsi untuk penampilan secara langsung nilai suhu yang terbaca.

10. Telegram

Berfungsi sebagai akhir penyimpanan data berupa gambar serta nilai suhu objek dari hasil proses mikrokontroler ESP32-CAM.

11. Water Pump Motor

Berfungsi untuk memberikan tekanan pada antiseptik agar dapat mengalir menuju ujung saluran yaitu Nozzle.

12. Misting Nozzle

Berfungsi untuk mengubah cairan antiseptik menjadi butiran-butiran kecil (Droplet) yang nantinya akan diberikan kepada objek berupa tubuh manusia secara merata. 


\section{B. Cara Kerja Alat}

Dengan menampilkan diagram alir (Flowchart) yang akan menampilkan hubungan Input, Process, dan Outputnya. Dari Flowchart akan menampilkan algoritma dari sistem alat tersebut. Flowchart akan dipaparkan pada gambar berikut :

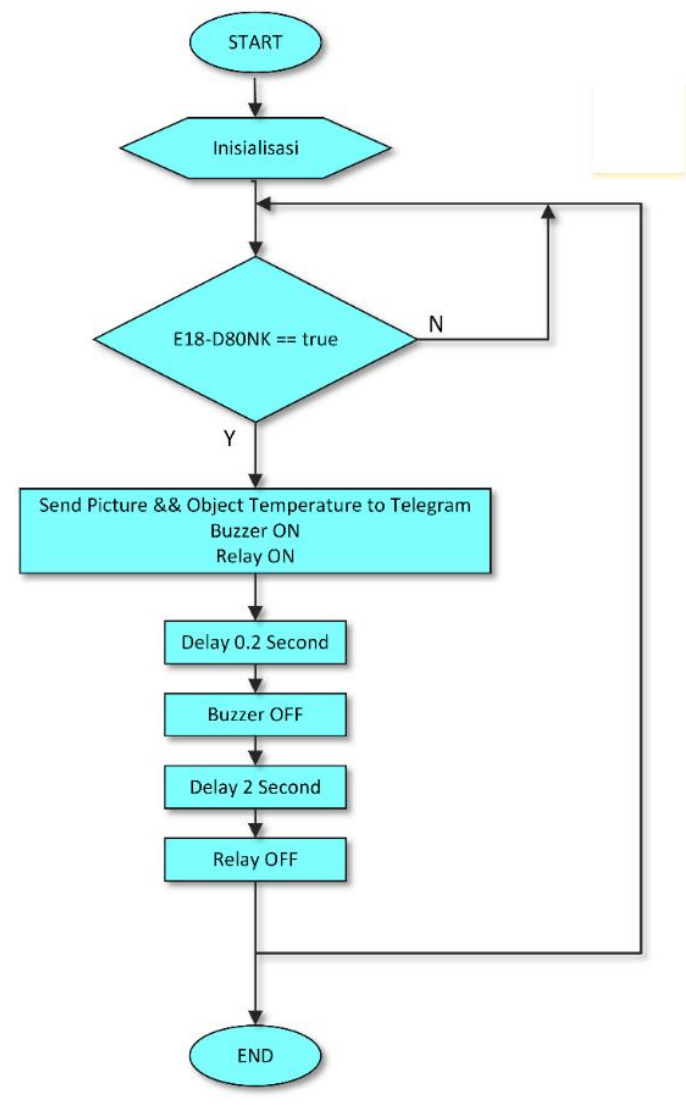

Gambar 2. Flowchart Alat

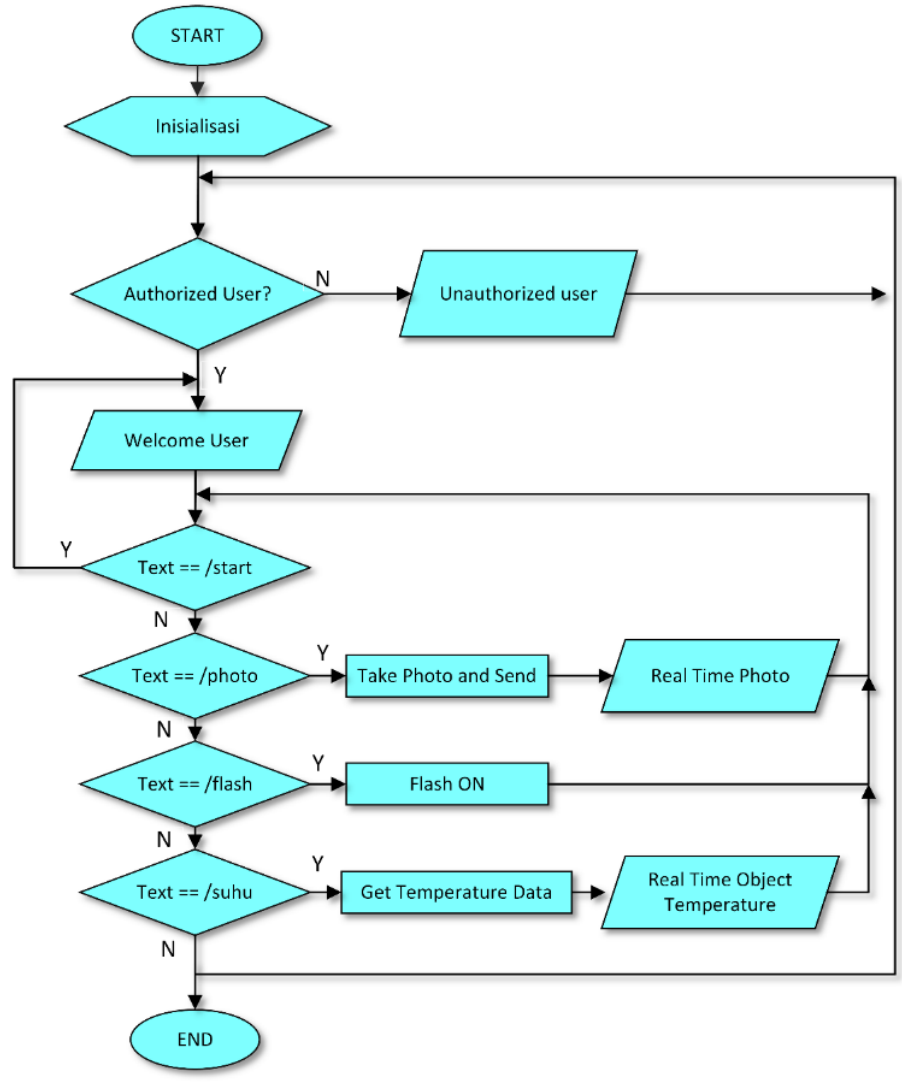

Gambar 3. Flowchart pada Aplikasi Telegram

Berikut algoritma yang akan dijelaskan sebagai berikut :

a. Pada alat

1. Mulai

2. Sensor E18-D80NK mendeteksi objek

3. Pengambilan gambar oleh kamera OV2640 serta suhu oleh sensor MLX90614 dan langsung diproses oleh ESP32-CAM untuk dikirimkan ke aplikasi Telegram

4. Buzzer hidup 0,2 detik dan Relay hidup 2 detik

5. Selesai

b. Pada aplikasi Telegram

1. Mulai

2. Verifikasi pengguna telegram

3. Welcome User

4. Perintah "/start" untuk mengetahui perintah yang tersedia

5. Perintah "/photo" digunakan untuk mengambil dan menampilkan foto secara langsung

6. Perintah "/flash" untuk menghidupkan lampu flash pada Board ESP32-CAM

7. Perintah “/suhu” digunakan untuk mengambil dan menampilkan suhu secara langsung.

8. Selesai 


\section{Perancangan Hardware}

Pada gambar perancangan menunjukan bentuk fisik dan bagian-bagian dari rancang bangun bilik kabut antiseptik dengan panjang 0.8 meter, lebar 1 meter dan tinggi 2 meter. Pada alat ini terdapat 2 Nozzle di sudut atas bilik bagian belakang, 2 Nozzle bagian depan dan 2 Nozzle di depan tengah bilik.

Di atas bilik terdapat kotak hitam yaitu ESP32-CAM yang berfungsi sebagai kendali (Controller) serta modul OV2640 sebagai pengambil gambar target. Kotak hitam bagian samping terdapat Sensor E18-D80NK sebagai pendeteksi adanya objek yang mana ketika terdeteksi alat akan mempersiapkan gambar target serta suhu untuk dikirmkan ke aplikasi Telegram. Dan juga terdapat sensor MLX90614 sebagai pengukur suhu target. Dibagian samping alat, tabung biru muda adalah tempat penampung cairan antiseptik yang dihubungkan ke Nozzle $0.2 \mathrm{~mm}$ melalui selang.

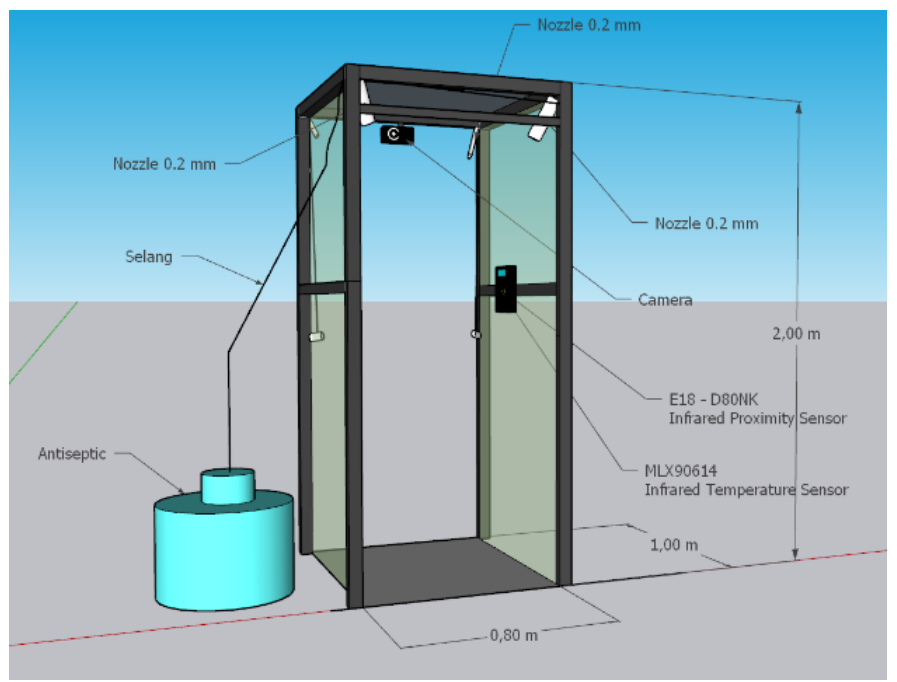

Gambar 4. Rancangan Desain Alat

\section{Rancangan Wiring Diagram Alat Secara Keseluruhan}

Rancangan Wiring Diagram alat ini menggunakan ESP32-CAM yang dipasok tegangan Power Supply 5 VDC dari Modul MB102 sehingga modul ESP32-CAM bekerja dan terhubung ke Wi-Fi, lalu sensor E18-D80NK akan mendeteksi objek berupa tubuh manusia dan diambil gambar melalui OV2640 serta diukur suhunya dengan sensor MLX90614. Gambar serta suhu manusia tersebut akan dikirim ke aplikasi Telegram. Setelah itu akan mengeluarkan Output berupa LCD 16x2 untuk menampilkan suhu serta motor pompa (Water Pump Motor) yang berfungsi sebagai memberikan tekanan dan mengalirkan fluida berupa antiseptik ke Nozzle untuk dikabutkan.

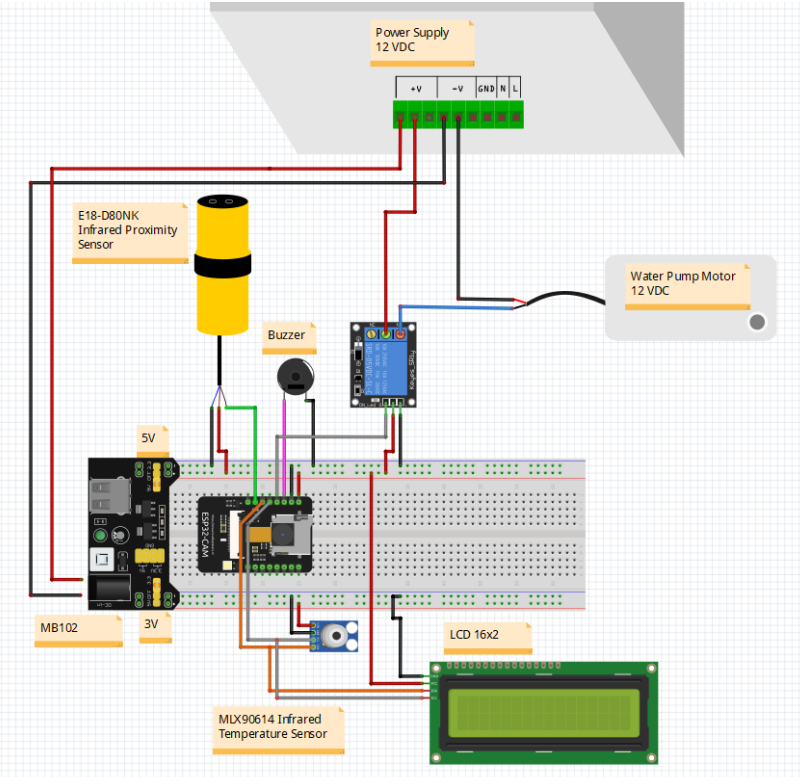

Gambar 5. Wiring Diagram Alat secara Keseluruhan

\section{HASIL DAN PEMBAHASAN}

Bagian ini dijelaskan bagaimana pengujian serta analisa sistem yang dimulai dari masing-masing komponen sampai alat pengujian dan analisa alat keseluruhan dan benar. Hal ini dilakukan agar dapat mengetahui apakah komponen alat dapat bekerja dengan baik. Pengujian dilakukan pada Hardware dan Software.

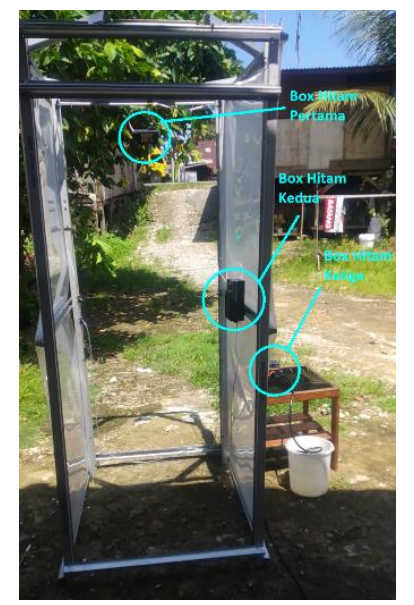

\section{Gambar 6. Rancangan Tampak Depan}

\section{Pengujian OV2640 Camera Module}

Pada bagian ini akan diperlihatkan apakah modul kamera OV2640 ini dapat bekerja dengan baik, dan dapat menampilkan gambar. Modul kamera OV2640 ini dihubungkan langsung pada tempat yang disediakan oleh ESP32-CAM sehingga modul kamera ini merupakan perangkat dari ESP32-CAM. 
Tabel 1. Hasil Pengujian Modul Kamera OV2640 pada ESP32-CAM

\begin{tabular}{|c|c|c|c|c|}
\hline No & Wi-Fi & Alamat IP & Tindakan & $\begin{array}{l}\text { Kamera } \\
\text { ov2640 }\end{array}$ \\
\hline 1 & Terhubung & $\begin{array}{l}\text { Diakses } \\
\text { melalui Web }\end{array}$ & $\begin{array}{l}\text { Klik } \\
\text { Tombol } \\
\text { Star } \\
\text { Stream }\end{array}$ & $\begin{array}{l}\text { Menampilkan } \\
\text { Gambar }\end{array}$ \\
\hline 2 & Terhubung & $\begin{array}{l}\text { Diakses } \\
\text { melalui Web }\end{array}$ & $\begin{array}{l}\text { Tidak Ada } \\
\text { Tindakan }\end{array}$ & $\begin{array}{l}\text { Gambar } \\
\text { Tidak } \\
\text { ditampilkan }\end{array}$ \\
\hline 3 & $\begin{array}{l}\text { Tidak } \\
\text { Terhubung }\end{array}$ & $\begin{array}{l}\text { Tidak } \\
\text { Menampilkan }\end{array}$ & $\begin{array}{l}\text { Tidak Ada } \\
\text { Tindakan }\end{array}$ & $\begin{array}{l}\text { Gambar } \\
\text { Tidak } \\
\text { ditampilkan }\end{array}$ \\
\hline
\end{tabular}

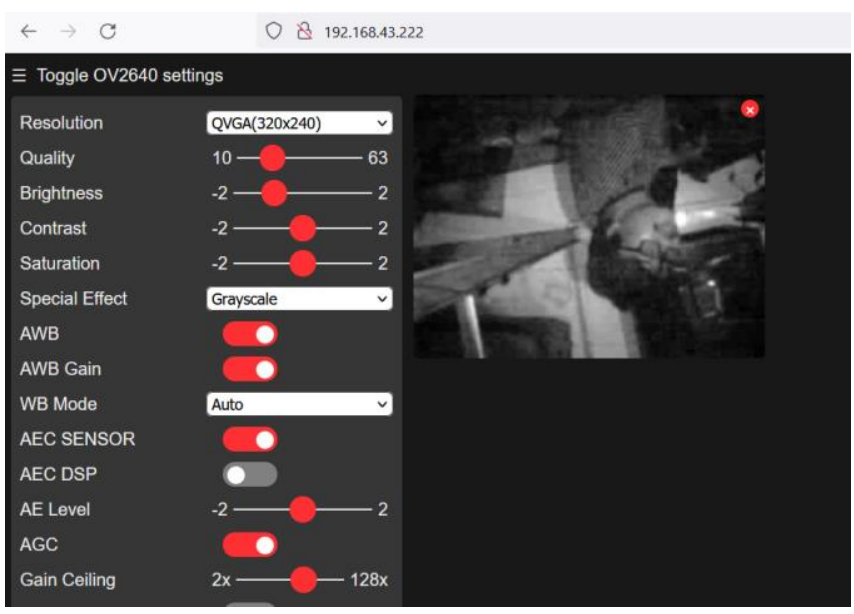

Gambar 7. Pengujian Modul Kamera OV2640 pada Web Server

Berdasarkan pengujian pada gambar diatas tampak bahwa modul kamera OV2640 aktif dan beroperasi dengan baik. Hal ini dilihat pada modul ini yang dapat menampilkan gambar.

\section{Pengujian MLX90614 Infrared Temperature Sensor dan LCD 16x2}

Pada bagian ini akan diperlihatkan apakah modul MLX90614 ini dapat bekerja dengan baik, dan dapat mendapatkan nilai suhu serta menampilkan nilai suhu pada LCD $16 x 2$.

Penulis akan melakukan pengujian apakah sensor dapat bekerja dengan baik dan mampu untuk membaca suhu yang ditampilkan di LCD 16x2. Hal ini dapat dilihat pada gambar berikut :

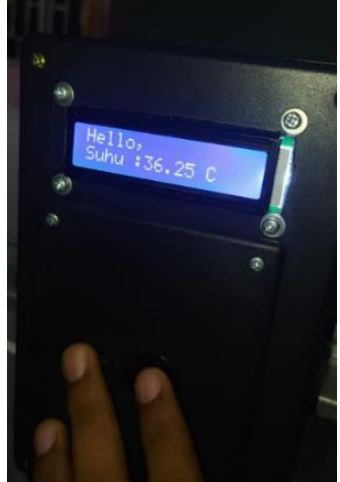

Gambar 8. Pengujian Sensor Suhu MLX90614 dan LCD 16x2

Pada gambar diatas tampak bahwa sensor MLX90614 dapat membaca suhu objek dengan baik serta dapat menampilkan data nilai suhu pada LCD 16x2.

penulis juga melakukan pengujian dari beberapa percobaan serta membandingkan dengan alat pendeteksi suhu konvesional salah satunya Thermogun AICARE Medical Infrared Thermometer Model A66. Pengujian dilakukan pada waktu yang berbeda serta dilakukan pada dini hari di salah satu ruangan dengan ventilasi angin. Hasil perbandingan dapat diamati pada tabel berikut :

Tabel 2. Hasil Pengujian dan Perbandingan Sensor Suhu MLX90614 dan Thermogun Konvesional

\begin{tabular}{|c|c|c|c|c|c|}
\hline \multicolumn{3}{|c|}{ MLX90614 } & \multicolumn{2}{|c|}{$\begin{array}{l}\text { Thermogun } \\
\text { Konvesional }\end{array}$} & \multirow{2}{*}{$\begin{array}{c}\text { Error } \\
\text { (Suhu Diukur } \\
\text { - Suhu } \\
\text { Terukur) }\end{array}$} \\
\hline No & Pukul & $\begin{array}{l}\text { Hasil } \\
\left({ }^{\circ} \mathrm{C}\right)\end{array}$ & Pukul & $\begin{array}{l}\text { Hasil } \\
\left({ }^{\circ} \mathrm{C}\right)\end{array}$ & \\
\hline 1. & $2: 42$ & 36,11 & $2: 42$ & 36,2 & $0.09{ }^{\circ} \mathrm{C}$ \\
\hline 2. & $2: 43$ & 36,27 & $2: 43$ & 36,2 & $-0.07^{\circ} \mathrm{C}$ \\
\hline 3. & $2: 44$ & 35,41 & $2: 44$ & 36,0 & $0.39^{\circ} \mathrm{C}$ \\
\hline 4. & $2: 45$ & 35,69 & $2: 45$ & 36,2 & $0.51^{\circ} \mathrm{C}$ \\
\hline 5. & $2: 46$ & 35,53 & $2: 46$ & 36,2 & $0.57^{\circ} \mathrm{C}$ \\
\hline 6. & $2: 47$ & 35,57 & $2: 47$ & 36,2 & $0.63^{\circ} \mathrm{C}$ \\
\hline 7. & $2: 48$ & 35,67 & $2: 48$ & 36,1 & $0.49{ }^{\circ} \mathrm{C}$ \\
\hline 8. & $2: 49$ & 35,91 & $2: 49$ & 36,1 & $0.19^{\circ} \mathrm{C}$ \\
\hline 9. & $2: 50$ & 36,05 & $2: 50$ & 36,2 & $0.15^{\circ} \mathrm{C}$ \\
\hline 10. & $2: 51$ & 35,63 & $2: 51$ & 36,2 & $0.57^{\circ} \mathrm{C}$ \\
\hline 11. & $2: 52$ & 35,99 & $2: 52$ & 36,2 & $0.21{ }^{\circ} \mathrm{C}$ \\
\hline 12. & $2: 53$ & 35,85 & $2: 53$ & 36,0 & $0.15^{\circ} \mathrm{C}$ \\
\hline 13. & $2: 54$ & 36,09 & $2: 54$ & 36,2 & $0.11^{\circ} \mathrm{C}$ \\
\hline 14. & $2: 55$ & 35,63 & $2: 55$ & 36,3 & $0.67^{\circ} \mathrm{C}$ \\
\hline 15. & $2: 56$ & 36,31 & $2: 56$ & 36,3 & $-0.01^{\circ} \mathrm{C}$ \\
\hline
\end{tabular}

Bedasarkan pembandingan pada tabel diatas diketahui bahwa suhu yang diukur dari objek dan waktu yang sama. Pembacaan suhu dari sensor MLX90614 terbilang cukup baik tetapi cenderung tidak tetap. Hal ini dikarenakan pengujian dilakukan di ruangan yang berangin dan dini hari dalam cuaca mendung yang menyebabkan pembacaan nilai sensor dipenggaruhi oleh suhu sekitarnya. 


\section{Pengujian E18-D80NK Infrared Proximity Sensor}

Pada bagian ini dijelaskan bagaimana E18-D80NK Infrared Proximity Sensor ini bekerja dengan baik serta mengatur jarak pembacaan sensor ini. Penulis mengatur jarak sebesar $5 \mathrm{~cm}$ untuk sensor ini. Oleh karena itu dilakukan pengujian apakah sensor dapat bekerja dengan baik dan menampilkan kondisi pada serial monitor Arduino IDE. Hal ini dapat dilihat pada gambar berikut :

Tabel 3. Pengujian Sensor E18-D80NK

\begin{tabular}{|c|c|c|}
\hline Uji Coba & Jarak & Status \\
\hline 1 & $1 \mathrm{~cm}$ & Terbaca \\
\hline 2 & $2 \mathrm{~cm}$ & Terbaca \\
\hline 3 & $3 \mathrm{~cm}$ & Terbaca \\
\hline 4 & $4 \mathrm{~cm}$ & Terbaca \\
\hline 5 & $5 \mathrm{~cm}$ & Terbaca \\
\hline 6 & $6 \mathrm{~cm}$ & Tidak Terbaca \\
\hline 7 & $7 \mathrm{~cm}$ & Tidak Terbaca \\
\hline \multicolumn{3}{|l|}{ ( сом5 } \\
\hline \multicolumn{3}{|c|}{ Tidak Terdeteksi } \\
\hline \multicolumn{3}{|c|}{ Tidak Terdeteksi } \\
\hline \multicolumn{3}{|c|}{ Tidak Terdeteksi } \\
\hline \multicolumn{3}{|c|}{ Terdeteksi } \\
\hline \multicolumn{3}{|c|}{ Terdeteksi } \\
\hline \multicolumn{3}{|c|}{ Terdeteksi } \\
\hline \multicolumn{3}{|c|}{ Tidak Terdeteksi } \\
\hline \multicolumn{3}{|c|}{ Tidak Terdeteksi } \\
\hline \multicolumn{3}{|c|}{ Terdeteksi } \\
\hline \multicolumn{3}{|c|}{ Terdeteksi } \\
\hline \multicolumn{3}{|c|}{ Tidak Terdeteksi } \\
\hline \multicolumn{3}{|c|}{ Tidak Terdeteksi } \\
\hline Tidak $\mathrm{T}$ & eksi & \\
\hline
\end{tabular}

\section{Gambar 9. Pengujian E18-D80NK pada Serial Monitor Aplikasi Arduino IDE}

Pada gambar diatas tampak bahwa sensor E18-D80NK mendeteksi objek dengan baik serta dapat menampilkan kondisi pendeteksian pada serial monitor Arduino IDE.

\section{Pengujian Pada Aplikasi Telegram}

Pengujian program pada aplikasi Telegram dilakukan untuk mengetahui bagaimana mengintegrasikan bot Telegram dengan ESP32-CAM.

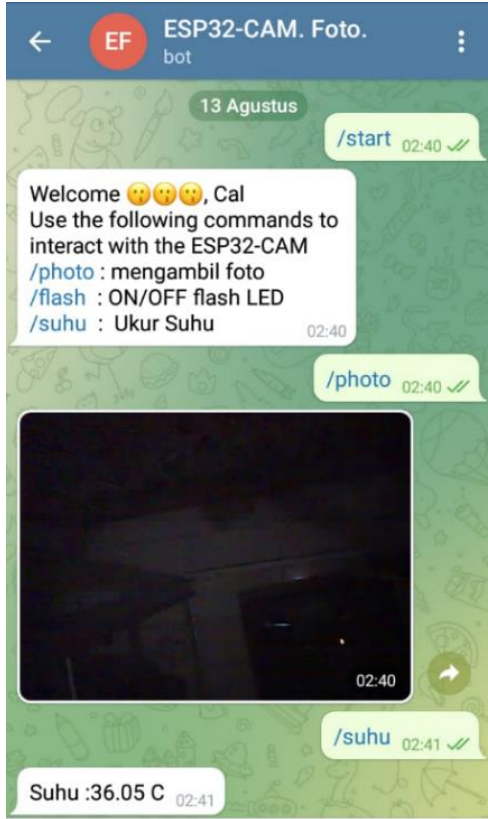

Gambar 10. Pengujian Hasil Interaksi ESP32-CAM dengan Aplikasi Telegram$$
\text { ๑ сом5 }
$$

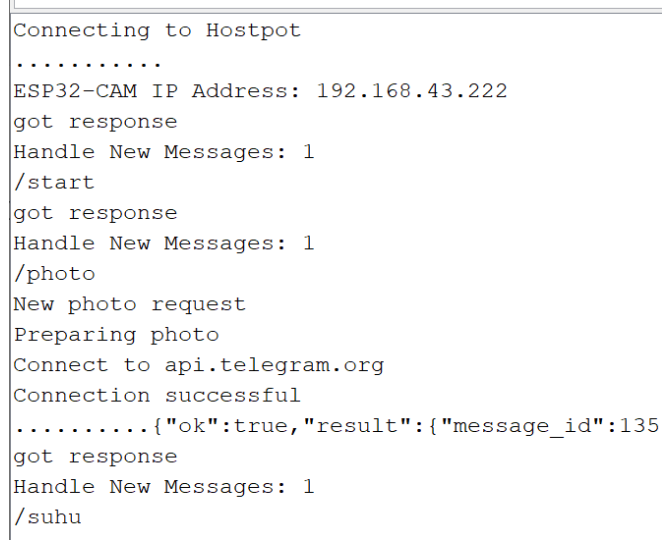

\section{Gambar 11. Pengujian Hasil Interaksi ESP32-CAM dengan Aplikasi Telegram pada Serial Monitor Arduino IDE}

Pada gambar diatas diperlihatkan bahwa ESP32-CAM dapat terhubung ke aplikasi Telegram melalui internet serta dapat melakukan interaksi antara Telegram dengan ESP32-CAM.

\section{Pengujian Alat Secara Keseluruhan}

Pengujian dilakukan penulis untuk melihat kinerja dari keseluruhan alat, mulai terhubungnya ESP32-CAM ke jaringan internet melalui Wi-Fi. Sensor E18-D80NK mendeteksi objek manusia lalu sensor suhu MLX90614 mengambil nilai suhu serta modul kamera 0V2640 akan mengambil gambar. ESP32-CAM akan memproses data gambar serta suhu dan mengirimkan langsung pada aplikasi Telegram. 
Tabel 4. Pengujian Alat secara Keseluruhan

\begin{tabular}{|c|c|c|c|c|c|}
\hline No & Pukul & Suhu & Gambar & $\begin{array}{c}\text { Status } \\
\text { Telegram }\end{array}$ & $\begin{array}{c}\text { Status } \\
\text { Pengujian }\end{array}$ \\
\hline 1. & $10: 38$ & $\begin{array}{l}36.63 \\
{ }^{\circ} \mathrm{C}\end{array}$ & & Terkirim & Berhasil \\
\hline 2. & $10: 41$ & $\begin{array}{l}36.35 \\
{ }^{\circ} \mathrm{C}\end{array}$ & & Terkirim & Berhasil \\
\hline 3. & $10: 44$ & $\begin{array}{l}35.97 \\
{ }^{\circ} \mathrm{C} \\
\end{array}$ & & Terkirim & Berhasil \\
\hline 4. & $10: 45$ & $\begin{array}{l}36.61 \\
{ }^{\circ} \mathrm{C}\end{array}$ & & Terkirim & Berhasil \\
\hline 5. & $10: 47$ & $\begin{array}{l}36.11 \\
{ }^{\circ} \mathrm{C}\end{array}$ & & Terkirim & Berhasil \\
\hline 6. & $10: 48$ & $\begin{array}{l}36.31 \\
{ }^{\circ} \mathrm{C}\end{array}$ & & Terkirim & Berhasil \\
\hline 7. & $11: 03$ & $\begin{array}{l}36.31 \\
{ }^{\circ} \mathrm{C} \\
\end{array}$ & & Terkirim & Berhasil \\
\hline 8. & $11: 04$ & $\begin{array}{l}36.59 \\
{ }^{\circ} \mathrm{C}\end{array}$ & & Terkirim & Berhasil \\
\hline
\end{tabular}

Setelah dilakukan 8 pengujian dengan target yang berbeda-beda didapatkan hasil yang cukup memuaskan dengan hasil persentase keberhasilan alat sebanyak 100\%.

$$
\begin{gathered}
\text { Persentase Keberhasilan }=\frac{\text { jumlah pengujian berhasi }}{\text { jumlah pengujian }} \times 100 \% \\
\text { Persentase Keberhasilan }=\frac{8}{8} \times 100 \% \\
\text { Persentase Keberhasilan }=100 \%
\end{gathered}
$$

\section{PENUTUP}

Setelah dilakukan pengujian Hardware, Software, serta analisa yang terkait, penulis dapat menemukan kesimpulan yaitu sebagai berikut :

1. Perancangan Misting Antiseptic Automatic pada pintu masuk berbasis Microcontroller beroperasi sesuai dengan tujuan dan memenuhi keinginan penulis dalam merancang alat tersebut. Hal ini dapat dilihat pada tabel 4 ketika alat yang dapat mengirimkan data berupa gambar dan suhu ke aplikasi Telegram.

2. Kamera OV2640 dan sensor MLX90614 pada alat Misting Antiseptic Automatic pada pintu masuk berbasis Microcontroller ini dapat melakukan pengiriman ke aplikasi Telegram harus melalui $W i-F i$ yang terhubung internet.

3. Interaksi antara alat Misting Antiseptic Automatic pada pintu masuk berbasis Microcontroller dengan aplikasi telegram dihubungkan dengan Wi-Fi melalui internet. Alat ini beroperasi dengan baik. Hal ini dapat dilihat pada gambar 10 dengan alat yang menjalankan instruksi dari operator terhadap alat tersebut. Maka, ini merupakan salah satu penerapan konsep Internet of Things (IoT).

4. Memanfaaatkan teknologi Internet of Things (IoT) oleh operator untuk melakukan pemantauan sekitar melalui alat Misting Antiseptic Automatic pada pintu masuk berbasis Microcontroller melalui aplikasi Telegram.

\section{REFERENSI}

[1] I. Suprobowati, O. D., \& Kurniati, "Virologi," in Pusat Pendidikan Sumber Daya Manusia Kesehatan: Kementerian Kesehatan RI., 2018.

[2] B. A. Setyawan, T. Agustianto, and S. F. Achmad Widodo, "Desain Portable Android Thermometer Fever (Prometer): Termometer Non-Kontak Praktis Berbasis Android," J. Din. Vokasional Tek. Mesin, vol. 5, no. 2, pp. 129-135, 2020, doi: 10.21831/dinamika.v5i2.34787.

[3] A. L. Larasati, D. Gozali, and C. Haribowo, "Penggunaan Desinfektan dan Antiseptik Pada Pencegahan Penularan Covid-19 di Masyarakat," Maj. Farmasetika, vol. 5, no. 3, pp. 137-145, 2020, doi: 10.24198/mfarmasetika.v5i3.27066.

[4] A. N. Trisetiyanto, "Rancang Bangun Alat Penyemprot Disenfektan Otomatis untuk Mencegah Penyebaran Virus Corona," J. Informatics Educ., vol. 3, no. 1, pp. 45-51, 2020.

[5] L. Gitleman, "Prototipe Ruang Sterilisasi Virus Berbasis Internet of Things," Pap. Knowl. . Towar. a Media Hist. Doc., no. Who, pp. 291-297, 2014.

[6] S. M. Andirani, "Desain Sistem Otomasi Bilik Disinfektan Berbasis Arduino Uno," J. EEICT (Electric, Electron. Instrumentation, Control. Telecommun., vol. 3, no. 1, pp. 33-39, 2020, doi: 
10.31602/eeict.v3i1.4565.

[7] F. R. Seke, "Sistem Kontrol Otomatis Misting Antiseptic Berbasis Mikrocontroller Untuk Meminimalisir Penyebaran Covid-19," J. Surya Energy, vol. 4, no. 2, pp. 367-373, 2020, doi: 10.32502/jse.v4i2.2511.

[8] R. I. Ndun, "Pengukur suhu tubuh manusia menggunakan sensor," Tugas Akhir Univ. Din., 2021.

[9] M. H. Habibullah, "Desain dan Implementasi Sensor untuk Penyemprotan Disenfektan sebagai Pengendali Virus Corona," Skripsi Univ. Muhammadiyah Surakarta, 2020.

[10] T. U. Urbach and W. Wildian, "Rancang Bangun Sistem Monitoring dan Kontrol Temperatur Pemanasan Zat Cair Menggunakan Sensor Inframerah MLX90614," J. Fis. Unand, vol. 8, no. 3, pp. 273-280, 2019, doi: 10.25077/jfu.8.3.273280.2019 .

[11] M. A. Auliq, D. A. Wicaksono, and M. Amrulloh, "Rancang Bangun Bilik Penyemprotan Covid 19 Menggunakan Sensor MLX90614 Berbasis Arduino," J. Tek. Elektro dan Komputasi, vol. 1814, pp. 1-15, 2021.

[12] R. Sahtyawan, A. B. Saputra, and S. Arief, "NodeMcu Microcontroller Based Disinfectant Fluid Monitoring System Using Water Level Control Sensor and Ultrasonic Sensor," Angkasa J. Ilm. Bid. Teknol., vol. 12, no. 2, pp. 141-150, 2020, doi: 10.28989/angkasa.v12i2.770.

[13] M. F. Wicaksono and M. D. Rahmatya, "Implementasi Arduino dan ESP32 CAM untuk Smart Home," J. Teknol. dan Inf., vol. 10, no. 1, pp. 40-51, 2020, doi: 10.34010/jati.v10i1.2836.

[14] K. Zuhri and A. Ihkwan, "Perancangan Sistem Keamanan Ganda Brangkas Berbasis Telegram Menggunakan Mikrokontroler ESP32-CAM," J. Teknol. dan Inform., vol. 1, no. 2, p. 1, 2020, [Online]. Available:

http://jurnal.umitra.ac.id/index.php/JEDA/article /view/470.

[15] F. Ratnasari, "Sistem Keamanan Rumah Berbasis IoT Menggunakan Mikrokontroler dan Telegram Sebagai Notifikasi," Seri Pros. Semin. Nas. Din. Inform., pp. 160-163, 2021.

\section{Biodata Penulis}

Ahmad Faisal, lahir di Jakarta Timur, 16 Juni 1999. Menyelesaikan Program Studi DIV Teknik Elektro Industri pada Jurusan Teknik Elektro Fakultas Teknik Unversitas Negeri Padang.

Habibullah, lahir di Kota Padang, 20 September 1982. Menyelesaikan S1 di Universitas Negeri Padang, S2 di Universitas Indonesia. Staff Pengajar serta Sekretaris Jurusan Teknik Elektro di Universitas Negeri Padang 